\title{
Ingestion of bacterial cells by the marine photosynthetic ciliate Myrionecta rubra
}

\author{
Geumog Myung ${ }^{1}$, Wonho Yih ${ }^{1, *}$, Hyung S. Kim ${ }^{1}$, Jong S. Park ${ }^{2}$, Byung C. Cho ${ }^{2}$ \\ ${ }^{1}$ Department of Oceanography, Kunsan National University, San 68, Miryong-dong, Kunsan 573-701, South Korea \\ ${ }^{2}$ Molecular and Microbial Ecology Laboratory, School of Earth and Environmental Sciences, Seoul National University, \\ Seoul 151-742, South Korea
}

\begin{abstract}
We report the first observation of fluorescently labeled bacteria (FLB) ingestion by the cells of MR-MAL01, a temperate strain of the marine photosynthetic ciliate Myrionecta rubra Jankowski 1976 (=Mesodinium rubrum Lohmann 1908). We also investigated the time course of ingestion and digestion of bacteria as well as the ingestion rates at 3 different light intensities. In the stationary phase of growth with ambient bacterial abundance $\left(1.4 \times 10^{6}\right.$ cells ml-1 $)$ under conditions of $15^{\circ} \mathrm{C}$ and $60 \mu \mathrm{E} \mathrm{m}^{-2} \mathrm{~s}^{-1}$, the rates of FLB uptake and disappearance of M. rubra MR-MAL01 cells were 7.6 and $5.3 \mathrm{FLB}_{\text {grazer }}{ }^{-1} \mathrm{~h}^{-1}$, respectively. The ingestion rate of $M$. rubra in cultures was calculated to be 53 bacteria grazer-1 $\mathrm{h}^{-1}$. The initial abundance of $M$. rubra (ca. $1.0 \times 10^{4} \mathrm{cells} \mathrm{ml}^{-1}$ ) in the ingestion-digestion experiment was comparable to the natural abundance during the $M$. rubra red tide in Korean coastal waters. The bacterivory rate of $M$. rubra increased gradually as light intensity decreased from 200 to $0 \mu \mathrm{E} \mathrm{m}{ }^{-2} \mathrm{~s}^{-1}$; this might enable the photosynthetic $M$. rubra to survive under intermittently light-limiting conditions. The present study showed a novel phenomenon of the ingestion of bacterial cells by $M$. rubra and the light-affected bacterivory rates of the common red tide ciliate.
\end{abstract}

KEY WORDS: Myrionecta rubra $\cdot$ Mesodinium rubrum $\cdot$ Bacterivory $\cdot$ Ingestion rate $\cdot$ Light intensity Mixotrophy $\cdot$ Red tide

\section{INTRODUCTION}

Myrionecta rubra Jankowski 1976 (=Mesodinium rubrum Lohmann 1908) is a marine kleptoplastidic (=retaining plastids of donor cells) ciliate that exhibits phototrophic ability during long periods between feedings on plastid donors (Johnson \& Stoecker 2005). As a functional primary producer, $M$. rubra is very common and often causes recurrent red tides in diverse marine pelagic environments, including fjords (Taylor et al. 1971, Lindholm 1985), polar water under ice, and in deep water of the adjacent seas (Putt 1990, Satoh \& Watanabe 1991, Stoecker et al. 1992, 1993, Perriss et al. 1995). M. rubra has been considered as an unculturable species (Lindholm 1985) ever since Charles Darwin described it as 'minute animalcula darting about, and often exploding' (Darwin 1845, Taylor et al. 1971), until recently when isolates were grown as laboratory cultures by 2 research groups (Gustafson et al. 2000, Kim 2002). Using an Antarctic strain that originated from McMurdo Sound, Gustafson et al. (2000) showed that $M$. rubra sequester organelles of ingested cryptophyte Teleaulax acuta cells; this enhances the photosynthetic growth of the M. rubra strain (Gustafson et al. 2000). The detailed feeding process and the degree of contribution of the cryptophyte ingestion to the enhanced growth of $M$. rubra were reported in another strain isolated from a temperate estuary (Yih et al. 2004). However, bacterivory by Myrionecta/Mesodinium species has not been seriously explored by food web researchers (Sanders et al. 1989, Sherr et al. 1991, Dolan \& Marrase 1995, Perez et al. 2000), except for Sorokin \& Sorokin (1996) and Sorokin et al. (1999). In the absence of any direct evidence on $M$. rubra bacterivory, the latter authors estimated considerable energy flow (ca. 100 calories $\mathrm{m}^{-2} \mathrm{~d}^{-1}$ ) from bacteria to 
'Mesodinium rubrum' in the ecosystem analysis of the Lena River estuary (Sorokin \& Sorokin 1996) and Po River Delta (Sorokin et al. 1999).

Here, we first report novel bacterivory by a temperate strain of Myrionecta rubra, namely MR-MAL01 (Yih et al. 2004), and its light-affected bacterivory rates. The present study might facilitate a better understanding of the multidimensional function of $M$. rubra in various marine ecosystems.

\section{MATERIALS AND METHODS}

Clonal culture of a temperate Myrionecta rubra strain. Clonal cultures of experimental M. rubra MRMAL01 and its prey species CR-MAL01 were established using the single cell isolation method (Guillard \& Ryther 1962) with water samples collected at Gomso Bay, Korea (see Yih et al. [2004] for isolation and culturing methodology). The mean cell volume and mean equivalent spherical diameter of M. rubra MR-MAL01 under the culture conditions $\left(15^{\circ} \mathrm{C}, 30 \mathrm{psu}\right.$, and continuous illumination of $60 \mu \mathrm{E} \mathrm{m} \mathrm{m}^{-2} \mathrm{~s}^{-1}$ in an $\mathrm{f} / 2$ culture medium) were $5996 \mu^{3}$ and $22 \mu \mathrm{m}$, respectively (Yih et al. 2004).

Preparation of fluorescently labeled bacteria. Ingestion and digestion rates of Myrionecta rubra on bacteria were measured using fluorescently labeled bacteria (FLB). Briefly, FLB were prepared as described by Sherr et al. (1987) by staining concentrated bacterial samples with 5-(4,6-dichlorotriazin-2yl) aminofluorescein (DTAF). Bacteria (length, 1.0 to $1.9 \mu \mathrm{m}$; width, 0.3 to $0.6 \mu \mathrm{m}$ ) for $M$. rubra cultures were concentrated to $200 \mathrm{ml}$ by hollow fiber ultrafiltration ( $0.1 \mu \mathrm{m}$ pore size) from $4 \mathrm{l}$ of $3 \mu \mathrm{m}$ prefiltered cultures. They were then centrifuged at $22000 \times g$ for $20 \mathrm{~min}$ to obtain pellets. The pellets were resuspended in $10 \mathrm{ml}$ of PBS solution (0.05 $\mathrm{M} \mathrm{Na}_{2} \mathrm{HPO}_{4}-0.85 \% \mathrm{NaCl}, \mathrm{pH}$ 9). Subsequently, $20 \mathrm{mg}$ of DTAF was added, and the cell suspensions were incubated at $60^{\circ} \mathrm{C}$ in a water bath for $2 \mathrm{~h}$. After incubation, the stained bacteria were centrifuged and washed 3 times with the PBS solution; the bacteria were then suspended in a $0.02 \mathrm{M}$ tetrasodium pyrophosphate- $0.85 \% \mathrm{NaCl}$ solution. The cell suspension was sonicated using a tapered microtip (model UP-400A, Sonicor Instrument) at a $30 \mathrm{~W}$ power level in order to disperse large clumps. DTAF-stained bacteria were collected onto a $0.2 \mu \mathrm{m}$ black polycarbonate filter for enumeration via epifluorescence microscopy. Aliquots $(10 \mathrm{ml})$ were frozen at $-20^{\circ} \mathrm{C}$ in $20 \mathrm{ml}$ plastic vials. The FLB stocks $(54 \mu \mathrm{l})$ were added to $100 \mathrm{ml} \mathrm{sam-}$ ples in $500 \mathrm{ml}$ polycarbonate bottles presoaked in $10 \%$ (vol./vol.) $\mathrm{HCl}$ and copiously rinsed with deionized water. The bacterial abundance in the M. rubra culture was measured by epifluorescence microscopy accord- ing to the method described by Porter \& Feig (1980). Briefly, bacterial samples were fixed with $0.2 \mu \mathrm{m}$ filtered, borate-buffered formalin (final conc., $2 \%$ ). Bacteria, which were stained with 4',6-diamidino-2phenylindole (DAPI) and collected on a $0.2 \mu \mathrm{m}$ black polycarbonate filter, were counted under UV excitation using an epifluorescence microscope.

Rates of FLB uptake and digestion at low light intensity. Myrionecta rubra cultures starved of their cryptophyte prey (Yih et al. 2004) for $20 \mathrm{~d}$ in the stationary phase of growth were maintained overnight under culture conditions of $15^{\circ} \mathrm{C}, 30 \mathrm{psu}$, and $60 \mu \mathrm{E} \mathrm{m}{ }^{-2}$ $\mathrm{s}^{-1}$ and used for the ingestion-digestion experiment. FLB were added to the $M$. rubra culture $\left(8.0 \times 10^{3}\right.$ cells $\mathrm{ml}^{-1}$ ) until $14.3 \%$ bacterial abundance was achieved in the ciliate culture $\left(1.4 \times 10^{6} \mathrm{cells} \mathrm{ml}^{-1}\right)$. The experimental design was to monitor the uptake of FLB until FLB per M. rubra cell stopped increasing with time, and then to effectively inhibit further uptake of FLB by a 10 -fold dilution with cultured media containing the same concentration of unlabeled bacteria as used in the initial culture. For the FLB uptake experiment, $5 \mathrm{ml}$ of subsamples were collected at $15 \mathrm{~min}$ intervals for $105 \mathrm{~min}$, fixed with ice-cold glutaraldehyde (final conc., $1 \%$ ), and refrigerated until microscopic examinations. The preserved subsamples were stained with DAPI and filtered onto black Nuclepore membrane filters $(0.8 \mu \mathrm{m}$ pore size), and at least 100 microscopic fields were counted. The filters were first observed under UV excitation at a magnification of $\times 1000$. When an $M$. rubra cell was located, the incident light was switched to blue, and the number of FLB contained within the M. rubra cell were counted. The FLB uptake rate was calculated from the changes in the number of FLB grazer $^{-1}$ with time using simple regression analysis. The per cell clearance rate (nl grazer $\left.{ }^{-1} \mathrm{~h}^{-1}\right)$ was calculated by dividing the cell-specific uptake rate of FLB by the concentration of FLB per nl. The bacterivory rate was measured over the linear portion of the uptake curve. After $2 \mathrm{~h}$ of initial subsampling, $50 \mathrm{ml}$ of the remaining culture was diluted with $450 \mathrm{ml}$ of $3 \mu \mathrm{m}$ filtered seawater containing the appropriate number of bacteria $\left(2.17 \times 10^{6} \mathrm{cells} \mathrm{ml}^{-1}\right)$ to approximate the total concentration of bacteria initially present in the $M$. rubra culture. This treatment served to decrease the further uptake of FLB to a 10-fold lower rate while maintaining the same rate of bacterivory by keeping the total bacterial concentration constant. Subsamples $(40 \mathrm{ml})$ were collected in $500 \mathrm{ml}$ polycarbonate bottles at 15 min intervals for $105 \mathrm{~min}$ to monitor the decrease in FLB per $M$. rubra cell with time. The subsamples were examined for FLB per $M$. rubra cell as described earlier. A decreasing rate of FLB per M. rubra cell was determined via regression analysis for the linear portion of the curve for the digestion experiment. 
Rates of FLB uptake at 3 different light intensities. Aliquots of a Myrionecta rubra culture that was starved of its cryptophyte prey for $7 \mathrm{~d}$ were transferred to 3 separate bottles. Under conditions of $15^{\circ} \mathrm{C}$ and 30 psu conditions, each of the 3 bottles was maintained overnight at 0,60 , and $200 \mu \mathrm{E} \mathrm{m}^{-2} \mathrm{~s}^{-1}$ continuous illumination. The 3 different experimental cultures of $M$. rubra $\left(8.0 \times 10^{3}\right.$ cells $\left.\mathrm{ml}^{-1}\right)$ with initial bacterial concentration of $9.8 \times 10^{6}$ cells $\mathrm{ml}^{-1}$ and FLB concentration of $3.6 \times 10^{5} \mathrm{FLB} \mathrm{ml}^{-1}$ were used for the light intensity experiments. Subsamples $(25 \mathrm{ml})$ were collected in duplicate $500 \mathrm{ml}$ polycarbonate bottles at $10 \mathrm{~min}$ intervals for $30 \mathrm{~min}$ to monitor the number of FLB per $M$. rubra cell with time. The subsamples were fixed with ice-cold glutaraldehyde (final conc., 1\%) and examined for FLB per M. rubra cell as described earlier. The initial abundance of $M$. rubra (ca. $1.0 \times 10^{4}$ cells ml ${ }^{-1}$ ) and bacteria $\left(10^{6}\right.$ to $10^{7}$ cells $\left.\mathrm{ml}^{-1}\right)$ in the above experiments is comparable to their natural abundances during the $M$. rubra red tide in Korean coastal waters (G. Myung unpubl. data).

\section{RESULTS AND DISCUSSION}

\section{Ingestion of FLB by Myrionecta rubra cells}

FLB were clearly observed inside most of the Myrionecta rubra cells (Fig. 1); this was the first direct evidence of bacterivory by $M$. rubra. However, we could not observe the actual feeding process. The FLB count per $M$. rubra cell increased almost linearly from 0 to 30 min (Figs. 2 \& 3A). Although Sorokin \& Sorokin (1996) and Sorokin et al. (1999) have repeatedly postulated considerable energy flow from bacteria to $M$. rubra in their ecosystem model, the possibility of $M$. rubra ingesting bacterial cells has never been experi-
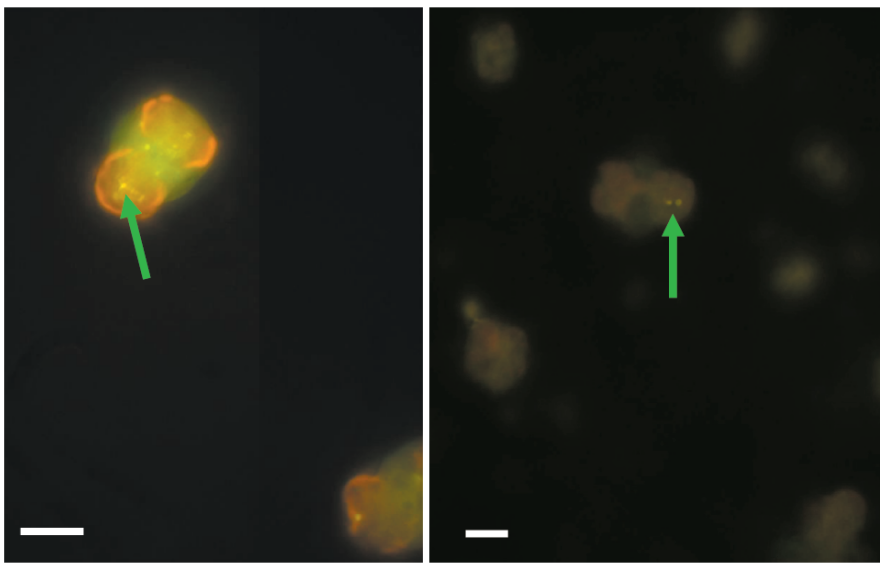

Fig. 1. Myrionecta rubra. Epifluorescence image of the ingested fluorescently labeled bacteria (small yellow dots indicated by arrows) inside the reddish-brown cells. Scale bars $=10 \mu \mathrm{m}$ mentally tested. Early observations that M. rubra lacks a true cytostome (Bary \& Stuckey 1950, Hibberd 1977, Grain et al. 1982) led many researchers to pay little attention to the trophic modes other than the 'obligatory' phototrophism (Sieburth et al. 1978, Smith \& Barber 1979, Crawford 1989) of the ciliate. However, recent reports have confirmed that phagotrophism, particularly on cryptophyte cells, as well as phototrophism is required for the sustainable growth of M. rubra. Gustafson et al. (2000) demonstrated the absolute requirement of the cryptophyte prey using an Antarctic isolate of $M$. rubra. Using another temperate M. rubra strain, Yih et al. (2004) reported a more detailed feeding process and the degree of contribution of algivory to the enhanced growth of $M$. rubra. Thus, the issue of the absence of a cytostome in $M$. rubra (Bary \& Stuckey 1950) needs further thorough examination. The formation and disappearance of the temporary cytostome-like structure at the anterior tip of the ciliate body might be an aspect for further exploration (Yih et al. 2004).

\section{Rates of FLB uptake and digestion of Myrionecta rubra starved for $20 \mathrm{~d}$ at low light intensity}

At $60 \mu \mathrm{E} \mathrm{m} \mathrm{m}^{-2} \mathrm{~s}^{-1}$ continuous illumination, the FLB count per Myrionecta rubra cell increased linearly from 0 to $60 \mathrm{~min}$ followed by 20 to $40 \mathrm{~min}$ of an 'equilibrium' period (Fig. 2). Based on the slope of the regression line for the data points between 0 and 60 min, the mean FLB uptake rate was calculated to be 7.6 FLB grazer ${ }^{-1} \mathrm{~h}^{-1}$; this yields a mean clearance rate

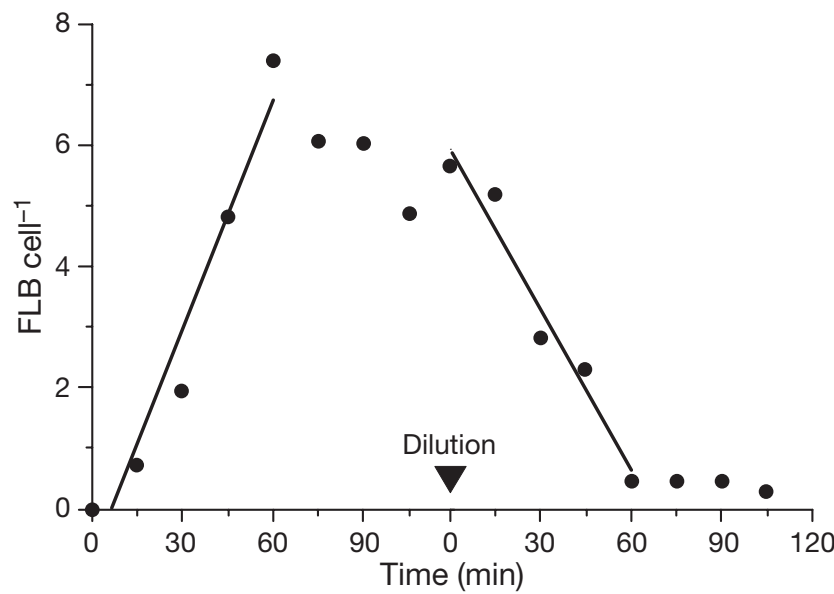

Fig. 2. Myrionecta rubra. Time course of ingestion and digestion of bacteria by the photosynthetic ciliate. In all cases, the correlation coefficients for the linear regression fits to the data were $>0.94$. Slopes of increase and decrease in fluorescently labeled bacteria (FLB) per cell were determined via regression analysis for the linear portions of the curves for each ingestion-digestion experiment 
of $37 \mathrm{nl}$ grazer $^{-1} \mathrm{~h}^{-1}$. The mean ingestion rates of $M$. rubra in the cultures was estimated to be 53 bacteria grazer $^{-1} \mathrm{~h}^{-1}$. The lower ingestion rate of the experimental $M$. rubra strain than that of other bacterivorous marine ciliate species (Sherr \& Sherr 1987, Sherr et al. 1989) might be associated with the mixotrophic nature of this strain.

Immediately after 10 -fold dilution of the ambient FLB concentration, the FLB count per Myrionecta rubra cell decreased linearly for $60 \mathrm{~min}$ from 5.8 to $0.5 \mathrm{FLB}_{\text {grazer }}{ }^{-1}$ to yield a mean disappearance rate of 5.3 FLB grazer ${ }^{-1} \mathrm{~h}^{-1}$ (Fig. 2). Therefore, the time taken by $M$. rubra to digest bacteria was $1 \mathrm{~h}$. This digestion time shows a good agreement with those obtained by other researchers. Fenchel (1975) reported digestion times of $30 \mathrm{~min}$ to $5 \mathrm{~h}$ for 2 bacterivorous ciliates within the temperature range of 7 to $25^{\circ} \mathrm{C}$. Fok \& Shockley (1985) found that the processing period in Tetrahymena species was $45 \mathrm{~min}$ at room temperature. The similar rates of FLB uptake and disappearance suggest that the plateau of the FLB uptake curve can be interpreted as the attainment of equilibrium between ingestion and digestion of FLB (Sherr et al. 1988).

\section{Rates of FLB uptake of Myrionecta rubra starved for $7 \mathrm{~d}$ at 3 different light intensities}

In all the experimental bottles, the FLB counts per Myrionecta rubra cell increased almost linearly from 0 to 30 min (Fig. 3A). The mean FLB uptake rates of the experimental $M$. rubra strain calculated at 0,60 , and $200 \mu \mathrm{E} \mathrm{m} \mathrm{m}^{-2} \mathrm{~s}^{-1}$ were 5.9, 3.6, and 2.6 FLB grazer ${ }^{-1} \mathrm{~h}^{-1}$, respectively (Fig. 3B). The estimated mean ingestion rate of the experimental $M$. rubra strain decreased from 159 to 70 bacteria grazer $^{-1} \mathrm{~h}^{-1}$ as the light inten-

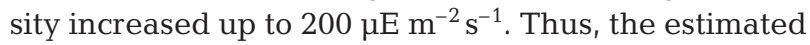
mean ingestion rate of the experimental $M$. rubra strain in the dark was ca. 2.3 times greater than that at

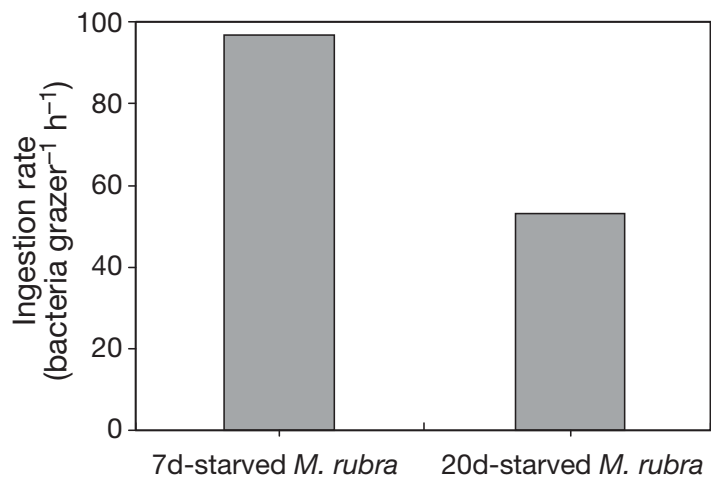

Fig. 4. Myrionecta rubra. Ingestion rate of bacteria by the photosynthetic ciliate decreased as the number of 'starved' days increased from 7 to 20 at $60 \mu \mathrm{E} \mathrm{m}$ m $^{-2} \mathrm{~s}^{-1}$ continuous illumination

$200 \mu \mathrm{E} \mathrm{m} \mathrm{m}^{-2} \mathrm{~s}^{-1}$. The significant reduction in the bacterivory rate at higher light intensities implies that $M$. rubra is at the phototrophic end of the scale of nutritional modes among marine mixotrophic protists (Bird $\&$ Kalff 1987, 1989). Bacterivory could serve as a source of substitutable organic matter for the phototrophic $M$. rubra under low light conditions (Rothhaupt 1996). Bacterivory of $M$. rubra should be further studied under diverse scales of nutrient limitation, bacterial abundance, light intensity and cell density of $M$. rubra before we can extrapolate the importance of $M$. rubra bacterivory to bloom as well as non-bloom conditions in nature.

\section{Effect of starvation period on Myrionecta rubra bacterivory}

The estimated mean bacterivory rate of the experimental Myrionecta rubra strain was significantly reduced when it was starved of prey cryptophyte cells for a longer period (Fig. 4). At $60 \mu \mathrm{E} \mathrm{m} \mathrm{m}^{-2} \mathrm{~s}^{-1}$, the $M$.
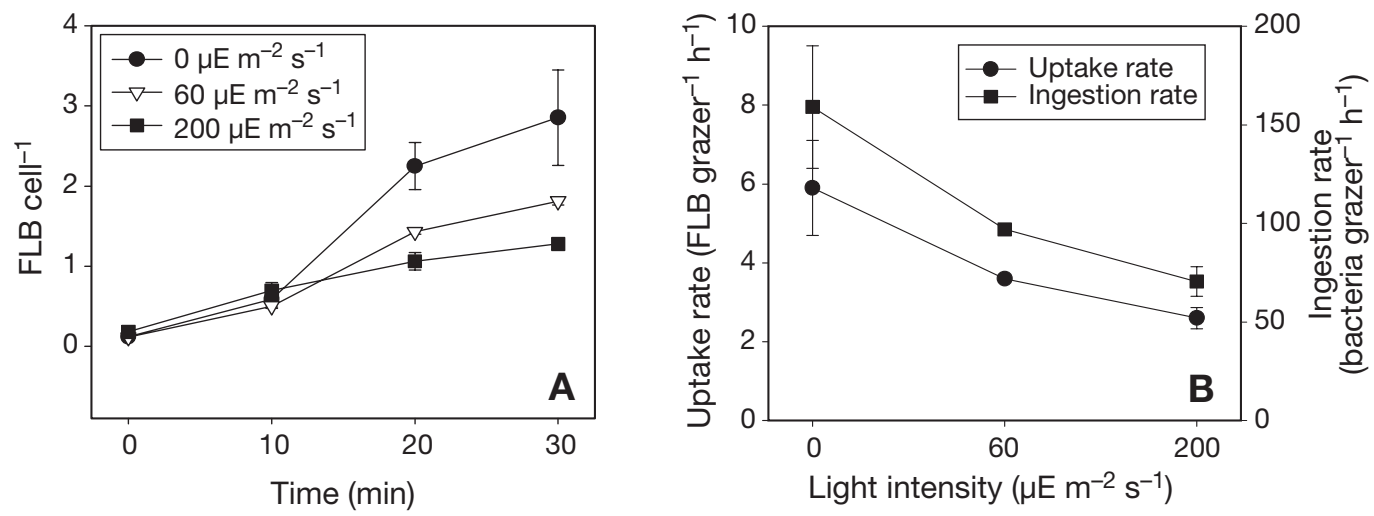

Fig. 3. Myrionecta rubra. Bacterivory rates of the experimental strain MR-MAL01 at 3 light intensities. (A) Time course of ingested FLB and (B) FLB uptake and ingestion rates at 0,60 , and $200 \mu \mathrm{E} \mathrm{m}^{-2} \mathrm{~s}^{-1}$ continuous illumination 
rubra starved for 20 d (Fig. 2) 7 d (Fig. 3) ingested 53 and 97 bacteria grazer ${ }^{-1} \mathrm{~h}^{-1}$, respectively (Fig. 4). In the present study, the 'old' $M$. rubra starved for $20 \mathrm{~d}$ might have been photo-physiologically more retarded than the 'relatively fresh' $M$. rubra starved for $7 \mathrm{~d}$. Similarly, the growth rate of the Antarctic $M$. rubra isolate gradually decreased with an increase in the 'unfed (=no addition of prey cryptophyte cells)' period (Johnson \& Stoecker 2005). It can be speculated that the photosynthetic process in the $M$. rubra culture that was starved for a longer period may be weakened, thereby diminishing the physiological need for substitutable organic matter or micronutrients obtained from the ingested bacterial cells (Nygaard \& Tobiesen 1993, Rothhaupt 1996).

In conclusion, the present study is the first to confirm that Myrionecta rubra exhibits bacterivory and may play an unrecognized role as a bacterivore, which may influence the nutrition of $M$. rubra; however, further research is required to confirm these assumptions.

Acknowledgements. We thank Dr. Hae Jin Jeong for comments on an earlier draft of our manuscript, and the 3 anonymous reviewers for their invaluable comments and suggestions. This study was supported by the NRL program of KOSEF (M1-0302-00-0068) and BK21 project of Korea.

\section{LITERATURE CITED}

Bary BM, Stuckey RG (1950) An occurrence in Wellington harbour of Cyclotrichium meunieri Powers, a ciliate causing red water, with some additions to its morphology. Trans R Soc NZ 78:86-92

Bird DF, Kalff J (1987) Algal phagotrophy: regulating factors and importance relative to photosynthesis in Dinobryon. Limnol Oceanogr 32:277-284

Bird DF, Kalff J (1989) Phogotrophic sustenance of a metalimnetic phytoplankton peak. Limnol Oceanogr 34:155-162

Crawford DW (1989) Mesodinium rubrum: the phytoplankter that wasn't. Mar Ecol Prog Ser 58:161-174

Darwin C (1845) Journal of researches into the natural history and geology of the countries visited during the voyage round the world of H.M.S. Beagle under the command of Captain Fitz Roy, R.N. A new edition with illustrations by R. T. Pritchett of places visited and objects described, 1913. John Murray, London

Dolan JR, Marrase C (1995) Planktonic ciliate distribution relative to a deep chlorophyll maximum: Catalan Sea, N.W. Mediterranean, June 1993. Deep-Sea Res I 42(11/12): 1965-1987

Fenchel T (1975) The quantitative importance of the benthic microfauna of an artic tundra pond. Hydrobiology 46: 445-464

Fok AK, Shockley BU (1985) Processing of digestive vacuoles in Tetrahymena and the effects of dichloroisoproterenol. J Protozool 32:6-9

Grain J, Puytorac P, Groliere CA (1982) Quelques precisions sur l'ultrastructure et la position systematique du cilie Mesodinium rubrum, et sut la constitution de ses symbiontes chloroplastiques. Protistologica 18:7-21

Guillard RRL, Ryther JH (1962) Studies of marine planktonic diatoms. I. Cyclotella nana Hustedt and Detonula confervacea (Cleve) Gran. Can J Microbiol 8:229-239

Gustafson DE, Stoecker DK, Johnson MD, Van Heukelem WF, Snaider K (2000) Cryptophyte algae are robbed of their organelles by the marine ciliate Mesodinium rubrum. Nature 405:1049-1052

Hibberd DJ (1977) Observations on the ultrastructure of the cryptomonad endosymbiont of the red-water ciliate Mesodinium rubrum. J Mar Biol Assoc UK 57:45-61

Jankowski AW (1976) Revision of a system of cyrtophorines. In: Markevich AP, Poljansky YI (eds) Materials of the II All-Union Conference of Protozoologists, Part I, General Protozoology. Naukova Dumka, Kiev, p 167-168

Johnson MD, Stoecker DK (2005) Role of feeding in growth and photophysiology of Myrionecta rubra. Aquat Microb Ecol 39:303-312

Kim HS (2002) Population dynamics and environmental conditions for the continuous growth of the phototrophic ciliate, Mesodinium rubrum in Korean West Coast. PhD thesis, Kunsan National University, Kusan

Lindholm T (1985) Mesodinium rubrum-a unique photosynthetic ciliate. Adv Aquat Microbiol 3:1-48

Lohmann H (1908) Untersuchung zur Feststellung des vollständigen Gehaltes des Meeres an Plankton. Wiss Meeresunters Kiel 10:129-370

Nygaard K, Tobiesen A (1993) Bacteriviory in algae: a survival strategy during nutrient limitation. Limnol Oceanogr 38:273-279

Perez MT, Dolan JR, Vidussi F, Fukai E (2000) Diel vertical distribution of planktonic ciliates within the surface layer of the NW Mediterranean (May 1995). Deep-Sea Res I 47:479-503

Perriss SJ, Laybourn-Parry J, Marchant HJ (1995) Widespread occurrence of populations of the unique autotrophic ciliate Mesodinium rubrum (Ciliophora: Haptorida) in brackish and saline lakes or the Vestfold Hills (eastern Antarctica). Polar Biol 15:423-428

Porter KG, Feig YS (1980) The use of DAPI for identifying and counting aquatic microflora. Limnol Oceanogr 25:943-948

Putt M (1990) Abundance, chlorophyll content and photosynthetic rates of ciliates in the Nordic Seas during summer. Deep-Sea Res 37(11):1713-1731

Rothhaupt KO (1996) Utilization of substitutable carbon and phosphorus sources by the mixotrophic chrysophyte Ochromonas sp. Ecology 77(3):706-715

Sanders RW, Porter KG, Bennett SJ, DeBiase AE (1989) Seasonal pattern of bacterivory by flagellates, ciliates, rotifers, and cladocerans in a freshwater planktonic community. Limnol Oceanogr 34:673-687

Satoh H, Watanabe K (1991) A red water-bloom caused by the autotrophic ciliate, Mesodinium rubrum, in the austral summer in the fast ice area near Syowa station, Antarctica, with note on their photosynthetic rate. J Tokyo Univ Fish 78(1):11-17

Sherr BF, Sherr EB, Fallon RD (1987) Use of monodispersed, fluorescently labeled bacteria to estimate in situ protozoan bacterivory. Appl Environ Microbiol 53:958-965

Sherr BF, Sherr EB, Rassoulzadegan F (1988) Rates of digestion of bacteria by marine phagotrophic protozoa, temperature dependence. Appl Environ Microbiol 54:1091-1095

Sherr EB, Sherr BF (1987) High rates of consumption of bacteria by pelagic ciliates. Nature 325:710-711

Sherr EB, Rassoulzadegan F, Sherr BF (1989) Bacterivory by pelagic choreotrichous ciliates in coastal waters of the NW Mediterranean Sea. Mar Ecol Prog Ser 55:235-240

Sherr EB, Sherr BF, McDaniel J (1991) Clearance rates of $<6 \mu \mathrm{m}$ fluorescently labeled algae (FLA) by estuarine pro- 
tozoa: potential grazing impact of flagellates and ciliates. Mar Ecol Prog Ser 69:81-92

Sieburth JM, Smetacek V, Lens F (1978) Pelagic ecosystem structure: heterotrophic compartments of the plankton and their relationship to plankton size fractions. Limnol Oceanogr 23:1256-1263

Smith WO Jr, Barber RT (1979) A carbon budget for the autotrophic ciliate Mesodinium rubrum. J Phycol 15: 27-33

Sorokin YI, Sorokin PY (1996) Plankton and primary production in the Lena River Estuary and in the South-eastern Laptev Sea. Estuar Coast Shelf Sci 43:399-418

Sorokin YI, Sorokin PY, Ravagnan G (1999) Analysis of lagoonal ecosystems in the Po River Delta associated with intensive aquaculture. Estuar Coast Shelf Sci 48:325-341

Editorial responsibility: Robert Sanders,

Philadelphia, Pennsylvania, USA
Stoecker DK, Buck KR, Putt M (1992) Changes in the sea-ice brine community during the spring-summer transition, McMurdo Sound, Antarctica. I. Photosynthetic protists. Mar Ecol Prog Ser 84:263-278

Stoecker DK, Buck KR, Putt M (1993) Changes in the sea-ice brine community during the spring-summer transition, McMurdo Sound, Antarctica. II. Phagotrophic protists. Mar Ecol Prog Ser 95:103-113

Taylor FJR, Blackbourn DJ, Blackbourn J (1971) The redwater ciliate Mesodinium rubrum and its 'incomplete symbionts': a review including new ultrastructural observations. J Fish Res Board Can 28:391-407

Yih W, Kim HS, Jeong HJ, Myung G, Kim YG (2004) Ingestion of cryptophyte cells by the marine photosynthetic ciliate Mesodinium rubrum. Aquat Microb Ecol 36:165-170

Submitted: April 10, 2006; Accepted: July 6, 2006

Proofs received from author(s): August 23, 2006 